\title{
STRATEGI MENGURANGI KETIDAKPASTIAN INFORMASI PASCA BENCANA ALAM PADA ANAK PERANTAUAN ASAL PALU, SIGI DAN DONGGALA YANG TINGGAL DI JAKARTA
}

\author{
Donal Adrian
}

\author{
Program Studi IImu Komunikasi, Universitas Tadulako
}

Naskah diterima tanggal 23-11-2019, direvisi tanggal 24-11-2019, disetujui tanggal 27-11-2019

\begin{abstract}
Abstrak. Penelitian ini bertujuan (a) untuk mengenalisis dan mendeskripsikan strategi anak perantauan asal Palu, Sigi dan Donggala yang tinggal di Jakarta dalam mengurangi ketidakpastian informasi saat bencana alam terjadi dan (b) untuk mengenalisis dan mendeskripsikan tindakan komnikasi anak perantauan asal Palu, Sigi dan Donggala yang tinggal di Jakarta untuk membantu keluarga dan korban bencana alam lainnya. Metode penelitian menggunakan kualitatif dengan pendekatan studi kasus. Pengambilan infroman menggunakan snowball sampling. Teknik pengumpulan data yaitu wawancara mendalam (Indepth Interview) dan observasi langsung. Analisis data menggunakan cara pandang menurut Miles dan Huberman (1992: 1-2) bahwa terdiri dari tiga alur kegiatan yang terjadi secara bersamaan, yaitu : reduksi data, penyajian data,dan penarikan kesimpulan/verifikasi. Hasil penelitian menunjukkan bahwa terdapat beberapa strategi yang dilakukan oleh anak perantauan asal Kota Palu, Sigi dan Donggala yang tinggal di Jakarta yaitu (1) hanya menyaksikan pemberitaan melalui media massa dan media online, tanpa melakukan komunikasi secara langsung kepada pihak keluarga di Kota Palu, Sigi dan Donggala saat gempa awal terjadi dipukul 15.00 WITA, (2) saat bencana gempa, tsunami dan likuifaksi terjadi pukul 18.00 WITA, anak perantauan menghubungi keluarga yang tinggal dekat di daerah Sulawesi Tengah seperti Kabupaten Luwuk, Parigi Moutong, Poso, Morowali, Toli-Toli dan lainlain. Sedangkan untuk provinsi terdekat seperti Makassar, Manado, Pasangkayu dan Balikpapan. Tujuannya untuk mengetahui kondisi korban bencana. Strategi ke (3) jaringan komunikasi yang membaik membuat proses penyampaian pesan menjadi efektif seperti menanyakan kondisi diri korban dan memberikan semangat hidup, serta melakukan komunikasi timbal balik melalui curahan hati yang disampaikan oleh korban terhadap anak perantauan terkait dengan perjuangan untuk bisa selamat dari bencana, berjuangan mencari keluarga yang belum ditemukan dan berjuang melawan rasa trauma.

Kata kunci: anak perantauan, bencana alam, ketidakpastian informasi.
\end{abstract}

\begin{abstract}
Learning by using other media that is more interesting such as video (audio visual) can be tested on junior high school students because it has strengths and abilities that we can use to overcome existing limitations. This study aims to compare the knowledge of students in villages and cities when they are given material using video media. The method used is the pre and post test experiments. The results showed that the video learning media had a positive impact on learning outcomes because it was proven to increase student knowledge. However, in the case of students in rural schools the increase in knowledge was not as significant as in the cities. Video learning media have higher posttest scores on students in cities than students in villages. Furthermore, a very significant difference is shown in testing students' knowledge in cities and villages when given material exposure using video media. So, students in cities are more prepared to be given other learning methods such as video shows compared to students in villages. The development of learning methods with digital video media is more effective in students in cities than in villages.
\end{abstract}

Keywords: city, knowledge, video, village. 


\section{PENDAHULUAN}

Indonesia merupakan negara kepulauan yang terbentang indah dari Sabang sampai Merauke. Keindahan wilayah Indonesia bisa ditemui pada setiap sudut pulau mulai dari pegunungan hingga lautan. Provinsi Sulawesi Tengah merupakan salah satu daerah yang berada di wilayah kedaulatan negara Republik Indonesia yang memiliki keindahan alam dan siapa pun bisa menikmatinya. Namun, dalam kondisi tertentu, alam kemudian menunjukkan kekuatannya melalui bencana alam.

Pada tanggal 28 September 2018 Kota Palu, Donggala dan Sigi merupakan tiga daerah di Provinsi Sulawesi Tengah, merasakan terjadinya bencana alam yang maha dahsyat seperti gempa, tsunami dan likuifaksi. Hal ini disebabkan adanya pergeseran lempeng Palu Koro.

Menurut Kepala Pusat Data, Informasi, dan Hubungan Masyarakat Badan Nasional Penanggulangan Bencana (BNPB) Sutopo Purwo Nugroho menyampaikan kronologi gempa bumi dan tsunami yang terjadi di Kota Palu dan Kabupaten Donggala, Sulawesi Tengah, Jumat (28/9/2018). Sutopo menyatakan bahwa gempa pertama kali mengguncang Donggala pukul 14.00 WIB. Gempa tersebut berkekuatan magnitudo 6 dengan kedalaman $10 \mathrm{~km}$. Akibat gempa itu, satu orang meninggal dunia, 10 orang luka, dan puluhan rumah rusak di Kecamatan Singaraja, Kabupaten Donggala. Setelah itu, gempa kembali terjadi pukul 17.02 WIB dengan kekuatan yang lebih besar, yaitu magnitudo 7,4 dengan kedalaman yang sama, $10 \mathrm{~km}$ di jalur sesar Palu Koro. Kumber: Kas.com: https://nasional.kompas.com/read/2018/09/29/16415971/begini-kronologi-gempa-dan-tsunamipalu-donggala-yang-tewaskan-ratusan-orang/ diakses 20 Novermber 2018).

Kondisi awal gempa yang terjadi di wilayah Kabupaten Donggala tentunya membuat masyarakat menjadi panik dan resah. Namun, kepanikan itu tidak hanya dirasakan oleh masyarakat Donggala. Kabupaten Sigi dan Kota Palu sebagai ibu kota provinsi juga merasakan hal yang sama. Gempa yang terjadi kemudian disusul lagi dengan adanya tsunami dan likuifaksi.

Terkait dengan bencana alam di Kota Palu dan sekitarnya lebih lanjut disampaikan oleh Sutopo bahwa gempa tersebut tergolong gempa dangkal dan berpotensi memicu tsunami. "Gempa ini adalah gempa yang dangkal akibat jalur sesar Palu Koro yang dibangkitkan oleh deformasi dengan mekanisme pergerakan struktur sesar mendatar miring, dan gempa ini berpotensi memicu tsunami," kata Sutopo di kantor BNPB, Utan Kayu, Jakarta Timur, Sabtu (29/9/2018). Lima menit pascagempa, Badan Meteorologi, Klimatologi, dan Geofisika (BMKG) menyampaikan peringatan dini tsunami. "Ketika terjadi warning tsunami, BMKG menyatakan pada pukul 17.02 dengan status Siaga dan Waspada. Arti status Siaga, tinggi tsunami adalah 0,5-3 meter untuk di pantai barat Donggala. sedangkan Waspada, kurang dari setengah meter Kota Palu bagian barat," ujar Sutopo. Saat itu, menurut Sutopo, pihaknya tengah menyiapkan rilis untuk mengimbau masyarakat supaya menjauhi kawasan pantai dan sungai dalam kurun waktu 30 menit. Namun, 30 menit setelah dikeluarkan peringatan tersebut, BMKG mencabutnya pada pukul 17.37 WIB. Akan tetapi, tsunami benar-benar terhadi pada pukul 17.22 WIB. Berdasar data BNPB, ketinggian tsunami ada yang mencapai 6 meter. Sejak gempa dan tsunami terjadi di Kota Palu dan Kabupaten Donggala, Jumat (28/9/2018), sejumlah gempa susulan terus terjadi di kawasan tersebut hingga Jumat malam. (Kompas.com: https://nasional.kompas.com/read/2018/09/29/16415971/begini-kronologi-gempa-dan-tsunamipalu-donggala-yang-tewaskan-ratusan-orang/ diakses 20 November 2018).

Bencana alam yang memporak-porandakan daerah Palu, Sigi dan Donggala mengakibatkan duka yang amat mendalam karena telah banyak menelan korban jiwa, mengakibatkan kerugian harta benda dan mengharuskan masyarakat yang selamat dari bencana untuk mengungsi ke daerah yang lebih aman. Meskipun pada saat itu, hanya dalam hitungan jam atau bahkan menit, gempa susulan sering terjadi.

Menurut Sutopo bahwa jumlah korban meninggal tersebar di beberapa lokasi. Di Palu korban tewas tercatat 1.703 orang, Donggala 171 orang, Sigi 223 orang, Parigi Moutong 15 orang, dan Pasangkayu 1 orang. Sedangkan korban luka-luka akibat gempa dan tsunami Palu mencapai 4.612 orang. Selain itu masih ada sebanyak 1.309 orang hilang sampai saat ini. "223.751 orang juga masih mengungsi di 122 titik," katanya. 
(https://nasional.tempo.co/read/1138400/jumlah-korban-tewas-terkini-gempa-dan-tsunami-palu2-113-orang/full\&view=ok/ Diakses 20 November 2018).

Bencana alam yang terjadi di Kota Palu, Sigi dan Donggala saat itu menjadi pemberitaan terpenting di Indonesia, tujuannya agar banyak masyarakat Indonesia dari Sabang sampai Merauke untuk bisa peduli dan saling membantu dalam meringankan beban korban bencana. Namun, ternyata pemberitaan tersebut bisa menyebabkan dampak psikis bagi keluarga yang tinggal di daerah lain, seperti anak perantauan yang berasal dari Palu, Sigi dan Donggala yang saat ini menetap di Jakarta. Mereka sangat cemas dan bercampur sedih karena dalam pemberitaan, daerah mereka porak-poranda disebabkan oleh guncangan gempa, terjangan tsunami dan adanya likuifaksi. Selanjutnya, anak perantauan tidak bisa menghubungi keluarga mereka karena jaringan telekomunikasi saat itu lumpuh total selama lebih kurang 3 hari dan bahkan lebih lama lagi. Keluarga yang tinggal di daerah Jakarta, hanya bisa menyaksikan perkembangan melalui pemberitaan media massa dan media on-line.

Kondisi yang dirasakan oleh anak perantauan Palu, Sigi dan Donggala merupakan bagian dari ketidakpastian informasi, meskipun mereka telah mendapatkan informasi berupa berita dari media. Namun itu tidak cukup untuk bisa menghilangkan rasa penasaran dan kecemasan mereka, karena berkomunikasi secara langsung dengan keluarga merupakan obat mujarab, disebabkan mereka akan bisa saling mengetahui perkembangan situasi dan kondisi di daerah bencana dan yang terpenting ialah untuk mengetahui apakah keluarga mereka selamat atau bahkan meninggal karena bencana alam tersebut.

Rumusan masalah dalam penelitian ini adalah (1) Bagaimana strategi anak perantauan asal Palu, Sigi dan Donggala yang tinggal di Jakarta dalam mengurangi ketidakpastian informasi saat bencana alam terjadi? (2) Bagaimana tindakan komnikasi anak perantauan asal Palu, Sigi dan Donggala yang tinggal di Jakarta untuk membantu keluarga dan korban bencana alam lainnya?

Tujuan Penelitian ini yaitu (1) Untuk mengenalisis dan mendeskripsikan strategi anak perantauan asal Palu, Sigi dan Donggala yang tinggal di Jakarta dalam mengurangi ketidakpastian informasi saat bencana alam terjadi; (2) Untuk mengenalisis dan mendeskripsikan tindakan komnikasi anak perantauan asal Palu, Sigi dan Donggala yang tinggal di Jakarta untuk membantu keluarga dan korban bencana alam lainnya.

Manfaat dalam penelitian ini adalah (1) Penelitian ini diharapkan mampu memperkaya kajian ilmu komunikasi terkait dengan mengurangi ketidakpastian informasi yang disebabkan oleh bencana alam; (2) Penelitian ini bisa membantu para peneliti selanjutnya untuk melakukan penelitian yang berkaitan dengan komunikasi bencana atau tentang komunikasi kelurga saat bencana terjadi.

Teori mengurangi ketidakpastian ini membahas proses dasar bagaimana kita memperoleh pengetahuan mengenai orang lain. Ketika kita bertemu dengan orang yang belum kita kenal maka biasanya banyak pertanyaan yang muncul dikepala kita, siapa dia? Mau apa? Bagaimaan sifatnya? dan seterusnya. Kita tidak memiliki jawaban yang pasti dan kita mengalami ketidakpastian, dan kita mencoba untuk mengurangi ketidakpastian ini. Menurut Berger (1997), orang mengalami periode yang sulit ketika menerima ketidakpastian sehingga ia cenderung memperkirakan perilaku orang lain, dan karenanya ia akan termotivasi untuk mencari informasi mengenai orang itu. Namun sebenarnya, upaya untuk mengurangi ketidakpastian inilah yang menjadi salah satu dimensi penting dalam membangun hubungan (relationship) dengan orang lain.

Ketika kita berkomunikasi, menurut Berger (1997), kita membuat rencana untuk mencapai tujuan kita. Kita merumuskan rencana bagi komunikasi yang akan kita lakukan dengan orang lain berdasarkan atas tujuan dan informasi atau data yang telah kita miliki. Semakin besar ketidakpastian maka kita akan semakin berhati-hati, kita akan semakin mengandalkan pada data yang kita miliki. Jika ketidakpastian itu semakin besar maka kita akan semakin cermat dalam merencanakan apa yang akan kita lakukan. Pada saat kita merasa sangat tidak pasti 
mengenai orang lain, maka kita mulai mengelami krisis kepercayaan terhadap rencana kita sendiri dan kita mulai membuat berbagai rencana cadangan atau rencana alternatif lainnya dalam hal kita memberikan respons pada orang lain.

Daya tarik dan keinginan berafiliasi yang ada pada diri indivdu memiliki hubungan positif dengan upaya mengurangi ketidakpastian. Tingkat ketidakpastian yang tinggi akan menciptakan jarak, sebaliknya ketidakpastian yang rendah akan cenderung menyatukan jarak. Ketika komunikator menemukan kesamaan dengan lawan biacaranya, maka ketertarikan diantara mereka akan meningkat dan kebutuhan mereka untuk mendapatkan lebih banyak informasi justru berkurang.

Berger (1997) mengatakan, orang dapat menempuh berbagai macam cara untuk mendapatkan informasi mengenai diri orang lain, namun secara umum berbagai cara itu dapat disederhanakan menjadi tiga strategi yaitu : (1) strategi pasif; (2) strategi aktif; dan (3) strategi interaktif. Anda menjalankan strategi pasif jika anda hanya melakukan pengamatan saja, sebaliknya jika anda secara aktif mencari informasi maka anda melakukan strategi aktif. Strategi interaktif mengandalkan komunikasi secara langsung dengan orang lain tersebut. Berger kemudian menguraikan masing-masing strategi tersebut :

1. Strategi pasif dibagi menjadi dua bentuk kegiatan pencarian informasi yang disebut dengan reactivity searching dan disinhibition searching.

a. Reactivity searching dilakukan dengan mengamati seseorang ketika ia sedang melakukan sesuatu atau mengamati bagaimana reaksinya pada situasi tertentu.

b. Disinhibition searching adalah strategi pasif lainnya, yaitu mengamati seseorang dalam situasi informal di mana ia dalam keadaan santai, tidak terlalu menjaga penampilannya (self monitoring) dan berperilaku apa adanya.

2. Pencarian informasi dengan menggunakan strategi aktif dilakukan dengan cara bertanya kepada orang lain mengenai seseorang yang ingin anda ketahui dan memanipulasi lingkungan sedemikian rupa agar orang yang menjadi target lebih muda untuk diamati.

Strategi interaktif mencakup kegiatan pengungkapan diri (self disclosure) yang merupakan strategi penting untuk mendapatkan informasi secara aktif, karena jika anda mengungkapkan sesuatu mengenai diri anda maka orang lain kemungkinan juga akan melakukan hal serupa.

\section{METODE PENELITIAN}

Penelitian yang digunakan adalah kualitatif dengan pendelatan studi kasus. Menurut Ratna (2010: 192-193) menjelaskan bahwa secara definitif bahwa studi kasus mensyaratkan suatu penelitian dengan kekhasan tertentu dan unik. Dalam hal ini peneliti sudah memiliki suatu pandangan bahwa di lokasi yang bersangkutan ada suatu masalah yang berbeda, bahkan mungkin menyimpang. Studi kasus sangat tepat apabila dikaitkan dengan penelitian kajian budaya, sebab pertama, sesuai dengan hakikatnya objek kajian budaya adalah segala sesuatu yang diperbuat oleh kebudayaan seperti masalah-masalah aktual yang muncul kepermukaan. Dua, studi kasus memberikan hak bersuara baik kepada orang yang tidak mempunyai kekuasaan (powerless) maupun tidak bersuara (voiceless). Teknik pengambilan sampel/informan yang digunakan adalah snowball sampling.

Teknik pengumpulan data yaitu Wawancara Mendalam (Indepth Interviewing) dan observasi langsung. Analisis data menggunakan cara pandang menurut Miles dan Huberman (1992: 1-2) bahwa terdiri dari tiga alur kegiatan yang terjadi secara bersamaan, yaitu : reduksi data, penyajian data,dan penarikan kesimpulan/verifikasi.

\section{HASIL PENELITIAN DAN PEMBAHASAN}

Bencana alam seperti gempa, tsunami dan likuifaksi yang terjadi di Kota Palu, Sigi dan Donggala menyebabkan banyak korban jiwa yang meninggal, harta benda yang hilang dan meninggalkan duka yang amat mendalam bagi korban selamat. Bencana alam yang terjadi pada tanggal 28 September 2018 tersebut menjadi pemberitaan nasional yang sangat diprioritaskan oleh hampir semua media baik massa ataupun on-line. Pemberitaan itu memiliki tujuan yang positif agar bisa mempersuasif seluruh masyarakat Indonesia bahkan nasional 
untuk bisa saling membantu baik secara psikis dan materi. Selanjutnya, di sisi lain ternyata pemberitaan melalui media ternyata memberikan kecemasan yang sangat tinggi bagi anak perantauan asal Palu, Sigi dan Donggala yang tinggal di Jakarta. Kecemasan terjadi disebabkan mereka hanya menerima informasi melalui media dan tidak bisa berkomunikasi secara langsung kepada keluarga, sehingga ketidakpastian informasi terjadi dalam diri setiap anak perantauan.

Saat terjadinya bencana hingga pasca bencana tiga hari dan bahkan lebih, komunikasi melalui jaringan telepon atau media on-line seperti whatshap, FB, Instagram dan lain-lain tidak bisa terhubungan dengan baik dan bahkan lumpuh total. Ini tentunya akan menambah kecemasan dan rasa kesedihan yang amat mendalam karena ketidakpastian informasi yang didapatkan terkait kondisi keluarga yang merasakan bencana alam seperti gempa, tsunami dan likuifaksi. Namun, meskipun sangat sulit untuk berkomunikasi, tentunya akan ada upaya untuk bisa mengurangi ketidakpastian tersebut.

Secara umum dijelaskan bahwa teori mengurangi ketidakpastian ini membahas proses dasar bagaimana kita memperoleh pengetahuan mengenai orang lain. Ketika kita bertemu dengan orang yang belum kita kenal maka biasanya banyak pertanyaan yang muncul dikepala kita, siapa dia? Mau apa? Bagaimaan sifatnya? dan seterusnya. Kita tidak memiliki jawaban yang pasti dan kita mengalami ketidakpastian, dan kita mencoba untuk mengurangi ketidakpastian ini. Menurut Berger (1997), orang mengalami periode yang sulit ketika menerima ketidakpastian sehingga ia cenderung memperkirakan perilaku orang lain, dan karenanya ia akan termotivasi untuk mencari informasi mengenai orang itu. Namun sebenarnya, upaya untuk mengurangi ketidakpastian inilah yang menjadi salah satu dimensi penting dalam membangun hubungan (relationship) dengan orang lain.

Fenomena yang terjadi terkait dengan bencana alam, yang kemudian mengakibatkan ketidakpastian informasi oleh anak perantauan asal Palu, Sigi dan Donggala yang tinggal di Jakarta mengakibatkan mereka melakukan berbagai macam strategi dengan tujuan untuk bisa mengetahui informasi jelas terkait dengan kondisi keluarga. Berikut penjabarannya:

\section{Sebelum Bencana Alam}

Sebelum terjadinya bencana alam yang maha dahsyat seperti gempa, tsunami dan likuifaksi di daerah Palu, Sigi dan Donggala, tentunya komunikasi yang terjalin antara anak perantaun dan keluarga berjalan dengan baik. Hal itu disebabkan jaringan komunikasi sangat stabil. Meskipun secara kronologis, Kabupaten Donggala merupakan daerah yang pertama kali diguncang oleh gempa pada pukul 15.00 wita. Ini sebenarnya bisa mengakibatkan tingkat kecemasan bagi anak perantauan di Jakarta, namun semuanya itu bisa teratasi dengan baik karena proses penyampaikan pesan melalui media maish berjalan dengan baik.

Tidak hanya anak perantauan yang berasal dari Donggala, anak perantauan dari daerah Kota Palu dan Sigi juga melakukan pengurangan ketidakpastian informasi dengan hanya melihat pemberitaan melalui media massa dan online. Mereka tidak merasa cemas dan takut disebabkan bencana gempa pada pukul 15.00 wita tersebut masih tergolong biasa saja. Sehingga mereka tidak perlu untuk melakukan komunikasi secara langsung melalui jaringan.

Pada dasarnya bahwa tindakan yang dilakukan oleh anak perantauan asal Palu, Sigi masuk dalam strategi pasif dibagi menjadi dua bentuk kegiatan pencarian informasi yang disebut dengan (a) Reactivity searching dilakukan dengan mengamati seseorang ketika ia sedang melakukan sesuatu atau mengamati bagaimana reaksinya pada situasi tertentu dan (b) Disinhibition searching adalah strategi pasif lainnya, yaitu mengamati seseorang dalam situasi informal di mana ia dalam keadaan santai, tidak terlalu menjaga penampilannya (self monitoring) dan berperilaku apa adanya, (Berger, 1997). 


\section{Saat Bencana Alam}

Bencana alam seperti gempa, tsunami dan likuifaksi yang terjadi di Kota Palu, Sigi dan Donggala tentunya membuat masyarakat menjadi panic dan berusaha menyelamatkan diri ke tempat yang lebih aman, misalnya saat gempa terjadi, orangorang banyak yang keluar dari dalam gedung atau rumah, namun tidak lama dari itu, mereka kembali masuk ke dalam rumah atau gedung yang lebih tinggi karena air tsunami yang datang dengan begitu dahsyat. Disamping itu, yang terkena dampak likuifaksi berusaha mencari tempat yang lebih aman seperti kepadatan tanah yang kuat. Mereka tidak hanya menyelamatkan diri sendiri, tapi mereka saling membantu antara yang satu dengan lainnya. Namun, dibalik banyaknya masyarakat yang selamat, banyak juga yang menjadi korban jiwa (meninggal).

Saat bencana alam terjadi, banyak masyarakat yang kehilangan sanak saudara, tetangga, teman dan orang terdekat lainnya. Kehilangan yang dimaksud dalam hal ini yaitu terkait dengan korban yang telah meninggal. Ini tentunya menambah kesedihan bagi para korban yang selamat.

Masalah yang berkaitan dengan bencana alam yang menyisahkan banyak korban hidup dan korban meninggal, tentunya menjadi pemberitaan yang sangat penting di berbagai media, baik massa dan online. Pemberitaan tersebut menjadi konsumsi informasi penting bagi hampir semua masyarakat Indonesia dari Sabang sampai Merauka, khususnya juga pada anak perantauan dari Palu, Sigi dan Donggala yang tinggal di Jakarta.

Selain menyaksikan pemberitaan bencana alam di Palu, Sigi dan Donggala, strategi anak perantauan yaitu saling bertanya kepada anak perantauan yang lain, menghubungi keluarga yang tinggal di beberapa kabupaten di Sulawesi Tengah seperti Kabupaten Luwuk, Parigi Moutong, Poso, Morowali, Toli-Toli dan lain sebagainya. Sedangkan untuk provinsi terdekat seperti Makassar, Manado, Pasangkayu dan Balikpapan. Tujuan menghubungi yaitu untuk menanyakan perkembangan informasi terkait dengan keluarga yang menjadi korban bencana alam, karena untuk melakukan komunikasi langsung sangat sulit, disebabkan jaringan komunikasi di daerah Palu, Sigi dan Donggala hilang total. Selanjutnya, strategi yang dilakukan oleh anak perantauan yaitu dengan mempersuasi keluarga yang berada di Kabupaten Luwuk, Parigi Moutong, Poso, Morowali, Toli-Toli dan lain-lain serta Makassar, Manado, Pasangkayu dan Balikpapan agar bisa secepat mungkin melakukan perjalanan darat dan laut untuk bisa membantu keluarga yang terkena dampak bencana alam.

Berdasarkan hasil temuan penelitian di atas, hal itu sesuai dengan penjelasan dari strategi aktif pada teori mengurangi ketidakpastian. Dijelaskan bahwa pencarian informasi dengan menggunakan strategi aktif dilakukan dengan cara bertanya kepada orang lain mengenai seseorang yang ingin anda ketahui dan memanipulasi lingkungan sedemikian rupa agar orang yang menjadi target lebih muda untuk diamati, (Berger, 1997).

\section{Setelah Bencana Alam}

Pasca bencana alam gempa, tsunami dan likuifaksi yang terjadi di Kota Palu, Sigi dan Donggala, masyarakat yang menjadi korban selamat umumnya tinggal di daerah pengungsian, karena tak sedikit dari mereka yang telah kehilangan tempat tinggal dan kehilangan orang terdekat. Kondisi yang dirasakan oleh masyarakat tersebut, tentunya selalu diberitakan oleh pihak media baik secara nasional dan bahkan sampai internasional. Pemberitaan yang secara terus menerus dilakukan sediktinya juga bisa memberikan informasi kepada siapapun, khususnya anak perantauan asala Kota Palu, Sigi dan Donggala yang tinggal di Jakarta. 
Beberapa hari setelah bencana terjadi, akses komunikasi mulai membaik meskipun durasi dalam berkomunikasi tidaklah terlalu lama. Proses penyampaian pesan yang dilakukan oleh anak perantauan dengan keluarga, teman atau bahkan orang terdekatnya yang berada di Kota Palu, Sigi dan Donggala berlangsung dengan penuh kesedihan. Awalnya anak perantauan menanyakan kondisi diri korban dan selanjutnya terjadi proses komunikasi di mana korban ceritakan bagaimana berjuang untuk bisa selamat, berjuangan mencari keluarga yang belum ditemukan dan berjuang melawan rasa trauma. Curahan hati yang disampaikan oleh korban tentunya ditanggapi dengan baik oleh anak perantauan seperti memberikan semangat hidup, berusaha untuk menghibur melalui candaan, dan selalu mengingatkan untuk ingat kepada Sang Pencipta. Tidak hanya melalui komunikasi, anak perantauan juga melakukan aksi penggalangan dana di Jakarta, dengan tujuan untuk bisa meringankan beban korban becana alam di Kota Palu, Sigi dan Donggala.

Timbal balik komunikasi yang efektif ditandai dengan menanyakan kondisi korban pasca gempa dan selanjutnya korban menyampaikan kesedihannya melalui curhan hati. Strategi yang dilakukan oleh anak perantauan tersebut sesuai dengan strategi interkatif. Dijelaskan bahwa strategi interaktif mencakup kegiatan pengungkapan diri (self disclosure) yang merupakan strategi penting untuk mendapatkan informasi secara aktif, karena jika anda mengungkapkan sesuatu mengenai diri anda maka orang lain kemungkinan juga akan melakukan hal serupa, (Berger, 1997).

\section{SIMPULAN}

Berdasarkan hasil penelitian di atas, maka kesimpulannya bahwa terdapat beberapa strategi yang dilakukan oleh anak perantauan asal Kota Palu, Sigi dan Donggala yang tinggal di Jakarta yaitu (1) hanya menyaksikan pemberitaan melalui media massa dan media online, tanpa melakukan komunikasi secara langsung kepada pihak keluarga di Kota Palu, Sigi dan Donggala saat gempa awal terjadi dipukul 15.00 WITA, (2) saat bencana gempa, tsunami dan likuifaksi terjadi pukul 18.00 WITA, anak perantauan menghubungi yang tinggal dekat di daerah Sulawesi Tengah seperti Kabupaten Luwuk, Parigi Moutong, Poso, Morowali, Toli-Toli dan Iainlain. Sedangkan untuk provinsi terdekat seperti Makassar, Manado, Pasangkayu dan Balikpapan. Tujuannya untuk mengetahui kondisi korban bencana. Selanjutnya, komunikasi persuasi dilakukan agar keluarga tersebut bisa dengan segera berkunjung ke Kota Palu, Sigi dan Donggala untuk membantu korban bencana.

Strategi ke (3) yaitu pasca bencana alam beberapa hari, jaringan komunikasi kembali membaik dan terjadilah proses penyampaian pesan seperti menanyakan kondisi diri korban dan memberikan semangat hidup, serta melakukan komunikasi timbal balik melalui curahan hati yang disampaikan oleh korban terhadap anak perantauan terkait dengan perjuangan untuk bisa selamat dari bencana, berjuangan mencari keluarga yang belum ditemukan dan berjuang melawan rasa trauma.

Saran dalam penelitian ini yaitu (a) Dari segi komunikasi, agar kita sebagai korban bencana alam yang masih hidup untuk tetap bisa saling memotivasi dan tetap mengingat kepada Sang Maha Pencipta; (b) Agar pemerintah pusat dan daerah bisa lebih sigap memberikan edukasi tentang bencana alam pada seluruh masyarakat Indonesia sehingga ada upaya untuk sesegera mungkin menyelamatkan diri supaya tidak banyak korban yang meninggal; (c) Untuk seluruh masyarakat Indonesia diharapkan agar tetap menjaga ikatan emosionalnya dengan cara saling membantu antara yang satu dengan yang lain tanpa memandang suku, agama, pendidikan, budaya dan lain-lain; (d) Agar media media mampu menyaring pemberitaan yang baik dan benar sehingga tidak terjaid hoax yang kemudian menjadikan masyarakat panic terkait bencana alam di Indonesia.

\section{DAFTAR PUSTAKA}

Berger, C. R. dkk. 1997. Planning Strategic Interaction: Attaining Goals Through Communicative Action. Lawrence Erlbaum 
Miles, Matthew B, dan Huberman, A. Michael. 1992. Qualitative Data Analysis. (Terjemahan: Tjetjep Rohendi dengan judul: Analisis Data Kualitatif), UI-Press: Jakarta

Ratna, Nyoman Kutha. 2010. Metodologi Penelitian Kajian Budaya dan IImu Sosial Humanioria Pada Umumnya. Pustaka Pelajar: Yogyakarta

https://nasional.tempo.co/read/1138400/jumlah-korban-tewas-terkini-gempa-dan-tsunami-palu2-113-orang/full\&view=ok/ Diakses 20 November 2018

https://nasional.kompas.com/read/2018/09/29/16415971/begini-kronologi-gempa-dan-tsunamipalu-donggala-yang-tewaskan-ratusan-orang/ diakses 20 November 2018

https://nasional.kompas.com/read/2018/09/29/16415971/begini-kronologi-gempa-dan-tsunamipalu-donggala-yang-tewaskan-ratusan-orang/ diakses 20 Novermber 2018 